\title{
THE INVESTMENT BANKERS' CASE: OBSERVATIONS IN REJOINDER
}

\author{
ROSCOE STEFFEN
}

MR. Whitney writes quite plausibly-by way of conclusion-that the Government's case ${ }^{1}$ against the investment bankers "simply evaporated," when it had to meet the statistical evidence introduced at the trial. He says thatwholly unbeknownst to Government counsel-the industry was "revolutionized"3 after 1937. But, though that is an intriguing thought, there are two points of law discussed earlier by Mr. Whitney which should first be dealt with briefly: the nature of the "offenses" charged in the complaint, and the distinction between "terms" and "means" in conspiracy pleading.

\section{"Integrated Over-all Conspiracy"}

It is stated flatly in my initial article that: "Of course, there is no "conspiracy' known to the law-integrated, over-all or otherwise-which comprises both 'monopoly' and 'restraint of trade." "4 That was said as a basis for the conclusion that Judge Medina committed manifest error, when he decided the case before him on the assumption that only a single conglomerate conspiracy had been charged. 5 But, to Mr. Whitney, the writer's statement is "patent error," to be disposed of in a footnote: "Innumerable cases have recognized that the same conspiracy can 'comprise' both."B In fact, he says Mr. Justice Douglas in United States $v$. Griffith $\tau$ "speaks of the defendants having 'formed a conspiracy in violation of $\$ 1$ and $\S 2$ of the Act." "s

But surely $\mathrm{Mr}$. Whitney can see that he is merely making a play on words, for there is a plain difference between conspiracy, i.e., the acts done, and conspiracy, i.e., the legal offense. The latter is a matter of statute, and even a first reading of sections 1 and 2 of the Sherman Act ${ }^{0}$ discloses that Congress did not provide for one "integrated over-all conspiracy," but for two separate offenses, with separate penalties for each. ${ }^{10}$ Nor did Mr. Justice Douglas say

$\doteqdot$ Professor of Law, University of Chicago. This is a replication to Mr. Wm. Dwight Whitney's article, The Intestment Bankers' Casc-Including A Reply to Professor Sieficn, 64 YALE L.J. 319 (1955) (hereinafter cited as Whitney).

1. United States v. Morgan, 118 F. Supp. 621 (S.D.N.Y. 1953).

2. Whitney, p. 344 .

3. Id. at 342 .

4. Steffen, The Investment Bankers' Case: Some Obserzations, 64 YALE L.J. 169, 177 (1954) (hereinafter cited as Steffen).

5. United States v. Morgan, 118 F. Supp. 621,629 (S.D.N.Y. 1953).

6. Whitney, p. 325 n.15.

7. 334 U.S. 100,109 (1948).

S. Whiney, p. 325 n. 15 .

9. 26 STAT. 209 (1890), as amended, 50 Stat. 693 (1937), 15 U.S.C. $\$ \$ 1,2$ (1952).

10. Perhaps Mr. Whitney is confused by such non-Sherman Act cases as MreDonnell v. United States, 19 F.2d 801, 803 (1st Cir. 1927), where the court said: "That the indict- 
disregard significant evidence of common practices on the part of the defenanything to the contrary in the Griffith case, for most of his opinion is devoted to a comparison of the two offenses-the conspiracy "in restraint of trade" under section 1 of the Act, and the conspiracy "to monopolize" under section 2. The sentence lifted out of context and relied on by Mr. Whitney meant simply that the defendants had so conducted themselves as to have committed both offenses, not that they were guilty of one conglomerate offense. ${ }^{11}$

Judge Medina's integration of the two offenses into one, moreover, was clearly reversible error. The cases are many pointing out that there are im. portant substantive differences between conspiracy in restraint of trade and conspiracy to monopolize. Ordinarily, where monopoly is found, it is the "end product" of restraint of trade, ${ }^{12}$ but, conversely, there are many conspiracies in restraint of trade which do not involve monopoly. When Judge Medina "integrated" the two charges into one offense, therefore, he improperly imposed a double burden on the Government. ${ }^{13}$ It enabled him to lay aside and dants, such as development and use of the syndicate "system,"14 the mainte-

ment charges in one count a conspiracy to commit two different offenses against the United States [one under the Tariff Act of 1922 and the other under the National Prohibition Act] does not make it bad for duplicity. Frohwerk v. United States, 249 U.S. 204, 209 .... The charge of conspiracy to commit two offenses is a charge of only one offense, namely, conspiracy." But the charge there, as the court pointed out, was brought under the general "conspiracy statute," 35 STAT. 1096 (1909), 18 U.S.C. $\$ 88$ (1940), now 62 SrAT. 701 (1948), 18 U.S.C. $\$ 371$ (1952). See also Blum v. United States, 46 F.2d 850 (6th Cir. 1931). To have brought the Bankers' case under that statute-which clearly was not done-would have involved the absurdity of charging defendants with having engaged in a "conspiracy" to engage in a "conspiracy" to restrain trade. Besides, the Bankers" case was a civil action, and the Government is given no civil remedy in the antitrust field to enforce $\S 371$. Its authority, as granted by $\S 4,26$ STAT. 209 (1890), as amended, 36 STrt. 1167 (1911), 15 U.S.C. $\S 4$ (1952), is "to prevent and restrain" violations of $\S 1$ and $\S 2$ of the Sherman Act, not violations of $\S 371$ of the Criminal Code.

11. Even as a pleading matter, there was no basis for "integrating" the two charges. As stated by Mr. Justice Holmes in Swift \& Co. v. United States, 196 U.S. 375, 395 (1905), a "bill in equity is not to be read and construed as an indictment would have been read and construed a hundred years ago, but it is to be taken to mean what it fairly conveys to a dispassionate reader by a fairly exact use of English speech."

12. In United States v. Griffith, 334 U.S. 100, 106 (1948), Mr. Justice Douglas said a person "usually does not violate $\S 2$ of the Sherman Act unless he has acquired or maintained his strategic position, or sought to expand his monopoly, or expanded it by means of those restraints of trade which are cognizable under $\$ 1$. For those things which are condemned by $\S 2$ are in large measure merely the end products of conduct which violated $\S 1$. Standard Oil Co. v. United States, 221 U.S. 1, 61. But this is not always true."

13. It meant that the Government had to prove not only an agreement to eliminate price-competition and to channelize distribution, that is, the conspiracy to restrain trade, but also that defendants had conspired to get "the cream of the business" for themselves, that is, the conspiracy to monopolize. The case was presented, however, and argued on summation, on the assumption that the court would, of course, pass on the restraint of trade charge separate from the monopoly charges. This the court failed to do.

14. United States v. Morgan, 118 F. Supp. 621, 683-84 (S.D.N.Y. 1953). Counsel for one of the defendants stated to the court that his client worked out "the first syndicate 
nance of resale prices, and so on, simply by pointing out that other nondefendant members of the industry engaged in similar practices. Plainly, the court did not rule on the restraint of trade case charged in the complaint.

\section{"Terms" and "Means"}

So, with the conspiracy in restraint of trade being set on its own bottom, so to speak, what are its "terms"? First, and most important, as briefly alleged in paragraph 43 of the complaint-the charging paragraph-they consist of an agreement on the part of the defendants to restrict, control, and fix "the channels and methods through which and the prices, terms, and conditions upon which security issues are merchandised ...."16 This was the central theme of the conspiracy in restraint of trade. ${ }^{10}$ But in paragraph 44 additional subsidiary "terms" are set out, together with some of the "means" by which the conspiracy so outlined is alleged to have been carried out.

Mr. Whitney, however, would have it that paragraph 44 was little, if anything, but a recital "of the very 'terms' of the conspiracy."17 This is a distortion of critical moment. Not that there is any magic in the words "terms" or "means,"18 but the plaintiff has the burden of establishing agreement upon the "terms" of a conspiracy.19 "Means," on the other hand, are in a sense but a description of some of the more significant evidence from which the court may infer that an agreement existed on the "terms" alleged. One or more of

agreement that was entered into on a several basis," in the summer of 1934. Transeript of Record, p. 7660, United States v. Morgan, 118 F. Supp. 621. (S.D.N.Y. 1953). Many other substantially similar provisions are in common use among defendants. Typical are the provisions as to the appointment of a manager, who is customarily given broad powers to make group sales, to handle all selling group matters, to terminate or extend the syndicate (i.e., to end or continue price maintenance), to stabilize, to be paid a fee by the other underwriters, and so on.

15. The full text is set out in Steffen, p. 172 n.21.

16. Mr. Whitney professes not to understand what is meant by a so-called "charging paragraph," unless it is labelled as such. Whitney, pp. 324-25. The "charging paragraph" in an antitrust pleading is readily distinguished--without a label-by the fact that it is the only paragraph which points out the provisions of the statute alleged to have been violated, and states the nature of the claimed offenses. Everything to follow is amplification, carefully described as such, and not the statement of new and independent "charges" or "offenses."

17. Whitney, p. 325.

18. A variety of expressions has been used. In Swift \& Co. v. United States, 196 U.S. 375, 396 (1905), Mr. Justice Holmes used the words "scheme" and "elements": "The scheme as a whole seems to us to be within reach of the law. The constituent elcments, as we have stated them, are enough to give the scheme a body and, for all that we can say, to accomplish it." (Emphasis added.) Justice Lurton in United States v. Reading Co., 226 U.S. 324, 344 (1912), spoke of the "combination" and the "steps" or "acts in furtherance" of it.

19. The Government, of course, assumed this burden throughout. See, c.g., Memorandum on the Over-All Conspiracy, May 29, 1951, Transcript of Record, p. 7942, United States v. Morgan, 118 F. Supp. 621 (S.D.N.Y. 1953). 
the "means" may not be proved at all; it is not necessary that each defendant be shown to have employed any one or more of them. ${ }^{20}$

The way paragraph 44 is articulated with the central charges stated in paragraph 43 , therefore, is a matter of importance. Mr. Whitney saw fit to quote only the opening sentence of paragraph 44 , which reads: "The conspiracy has consisted of a continuing agreement and concert of action among the defendants, the substantial terms of which have been that defendants :. ..."21 He then informs the reader-as he did the court-that everything following is therefore really only a statement of "terms." In his view, it seems, there vere no "means" alleged in the complaint.

Unfortunately for $\mathrm{Mr}$. Whitney's contention, the critical part of paragraph 44, which he failed to quote, continues in this way: "A. Agree not to compete among themselves for and in the merchandising of security issues . . among other means-(1) By employing the syndicate method," etc.,22 It is only too plain from this wording that paragraph 44A made it a further "term" of the conspiracy charged generally in paragraph 43 , that the defendants had agreed "not to compete among themselves." 23 But, it is surely equally clear that sub-

20. In United States v. General Dyestuff Corp., 57 F. Supp. 642, 645 (S.D.N.Y. 1944), Judge Rifkind said: "The crime is the conspiracy, Nash v. United States, 1913, 229 U.S. 373 .... The means do not qualify the charge of conspiracy, Jelke v. United States, 7 Cir., 1918, 255 F. 264, and need not be proved as alleged, United States v. Socony Vacuum Oil Co., 1940, 310 U.S. 150,250 . .." Then, with reference to the facts of the case before him, Judge Rifkind continued: "In other words, the indictment does not charge a violation of law by reason of the annexation of restraints on competition as ancillaries to the sale of a business but rather does charge the violation of law by reason of a principal agreement or conspiracy unreasonably to restrain competition, executed by means of conveyances with restrictive covenants annexed."

21. Whitney, p. 325.

22. The following is the full text:

"44. The conspiracy has consisted of a continuing agreement and concert of action among the defendants, the substantial terms of which have been that defendants:

"A. Agree not to compete among themselves for and in the merchandising of security issues, and to divide among themselves, on a mutually satisfactory basis, the merchandising of the security issues obtained by each of the defendant banking firms from issuers, among other means-

"(1) By employing the syndicate method to merchandise the security issues they handle.

"(2) By recognizing and deferring to the claims of the defendant traditional bankers to manage and co-manage and control the merchandising of the securities of particular issuers.

"(3) By determining their respective participations and positions in buying groups in accordance with the concept of historical position.

"(4) By reciprocally exchanging participations in the buying groups which they manage.

"(5) By adopting, maintaining, and stabilizing uniform prices, terms, and conditions of sale and resale for securities they merchandise to be adhered to by all participants in the merchandising thereof." (Emphasis added.)

23. Other subsidiary terms were stated in subparagraphs 44B and 44C. Defendants were alleged in $44 \mathrm{~B}$ to have agreed "to eliminate the competition of other investment bankers," and in $44 \mathrm{C}$ to have agreed "to prevent, restrain, minimize and discredit the use of competitive bidding." The allegation in each case again was concluded with the words 
paragraphs (1) to (5), inclusive, of paragraph 44A, relative to use of the syndicate system, historical position, reciprocity and other practices, are simply a statement of "means." 24 More words could not have made the point any" clearer.

Of such stuff, though, are decisions made.25 Observe what Mr. W'hitney can-and did-do with his point. Starting with the false premise that the "means" alleged in paragraph 44A (1)-(5) were really "terms," he says it was thus the Government's case "that the court should infer from the fact of umiform adherence to such termis that they had been agreed upon." 20 Of course, this never was the Government's case. ${ }^{27}$ On the contrary, the court was asked to look at all the various practices or "means" used by any one or all of the defendants, not in order to infer that such practices had been agreed upon, but to infer that defendants through their various activities were engaged in a common plan or scheme to eliminate price-competition between themselves, and to

\begin{abstract}
"among other means-(1) By ...." A "dispassionate reader," capable of understanding "a fairly exact use of English speech"-to use MIr. Justice Holmes' words-must surely" have read these paragraphs as alleging "terms" of the single conspiracy charged in paragraph 43, carried out by the various "means" described. Yet Judge Mledina, trusting defense counsel, read "means" to mean "terms," and then went on to treat each term as if it stated a wholly independent "charge" or "offense" Defendants' opposition to competitive bidding, for example, was not read as a "term" of the single restraint of trade conspiracy "charged" in paragraph 43 , but as a wholly separate "conspiracy" charge, to be disposed of all by itself. United States v. Morgan, 118 F. Supp. 621, 817 (S.D.N.Y. 1953).
\end{abstract}

24. Mr. Whitney appears to have misunderstood my initial article to say that paragraph 44 consisted only in a statement of "means." See Whitncy, p. 325. Actually, paragraph $44 \mathrm{~A}$ was spelled out as alleging a term of the conspiracy, that is, an agreement by defendants "not to compete among themselves." Steffen, p. 172. The many references thereafter to 44A (1), 44A (2), and so on, were plainly references to those subparagraphs, and, therefore, they were properly discussed as "means" only.

25. And, hence, the need for appellate courts.

26. Whitney, p. 326 (emphasis added). Failure on the part of the Government to establish "uniform adherence" to each such practice, meant, in Mr. Whitney's view, that "no case was left" There might be substantial agreement on the main terms of the conspiracy, as charged in paragraph 43 , but that was simply to be disregarded. The court must find that no forest, i.e., conspiracy, existed, if, on making a microscopic examination of each individual tree, i.e., means, he should find that there were differences, however minor.

27. Mr. Whitney quotes a colloquy between himself and the court, to show that Mrr. Baldridge agreed with his position. Id. at 326 n.19. But this is another case of lifting things out of context. What was being discussed is made clear by Judge Mfedina's next words, which Mr. Whitney failed to quote: "These are just part of what we call the mosaic here, and he [Mr. Baldridge] has been telling me, and I think with a great deal of justice, that every one of these things by itself may seem inconsequential, but the aggregate of them may not seem so. And I have to recognize that as being so." Transcript of Record, p. 4901, United States v. Morgan, 118 F. Supp. 621 (S.D.N.Y. 1953). It was not the Government, therefore, but Mrr. Whitney, who urged the up-side-down proposition-which ultimately prevailed-that evidence of the defendant's various practices was introduced so that the court might draw an "inference" that they-such practices-"had been agreed upon." 
channelize distribution. That was the conspiracy in restraint of trade and the only such conspiracy charged in the complaint. ${ }^{28}$

But, at some time during the openings, Judge Medina appears to have accepted the Whitney version. ${ }^{29}$ Indeed, he soon got "way out ahead"so of defense counsel, for he disposed of the case in his opinion as if the "means" stated in paragraph $44 \mathrm{~A}$ (1)-(4) were themselves the offenses charged." Moreover, and here even Mr. Whitney-quite properly-has nothing to say,

28. This was an action for equitable relief. It was enough, therefore, for the Government to prove an agreement on only one of the basic "terms" of the charge. Mr. Justice Douglas made this quite clear in United States v. Masonite Corp., 316 U.S. 265, 274 (1942): "We need not ... stop to explore all of the contentions made by the United States. They include arguments that there has been an illegal division of markets ...; that the 'agency' agreements have been used to control unlawfully other materials sold in combination with hardboard, the subject matter of Masonite's patents ... ; that, in some instances, the combination unlawfully controlled the price of hardboard 'owned' by the 'agents' . . ; and that the arrangement included agreements to suppress the use of patents . . . But we catn put these contentions to one side without expressing an opinion on them. For there is one phase of the case which is decisive. That is the agreement for price-fixing." (Emphasis added.)

29. Judge Medina may have been persuaded to this position by his experience in the Communist case. United States v. Foster, 9 F.R.D. 367 (S.D.N.Y. 1949). There, in an able charge to the jury, he said that, although the prosecution need not prove all of the "means" set out in the indictment, it was necessary to establish "that one or more of the means described in the indictment was agreed upon to be used to effect the conspiracy." Id. at 378 (emphasis added). But, of course, there is no requirement in antitrust law that the defendants be shown to have committed or agreed upon any "overt act" or "means." The point was settled long ago in Nash v. United States, 229 U.S. 373, 378 (1913), when Mr. Justice Holmes said: "Coming next to the objection that no overt act is laid, the answer is that the Sherman Act punishes the conspiracies at which it is aimed on the common law footing-that is to say, it does not make the doing of any act other than the act of conspiring a condition of liability." (Emphasis added.)

30. A phrase current at the trial.

31. A single illustration of the process must suffice. Some 1300 syndicate agreements, issued at different times over a period of 30 years or more, were put in evidence under paragraph $44 \mathrm{~A}(1)$, to show that defendants did use the syndicate method as one "means" by which they had conspired to eliminate price-competition and channelize distribution, all as charged in paragraph 43 . But the court-following carefully Mr. Whitney's teachings-turned his back completely on paragraph 43 , and then "spent many weeks" searching the batch of agreements before him for "uniformity." When he discovered-what everyone knew to start with-that there was "a conspicuous lack of uniformity" in delails, that was the end of the matter. The slyly substituted "conspiracy" to "use" the "syndicate system" (not the conspiracy charged) had blown up, i.e., "evaporated." United States v. Morgan, 118 F. Supp. 621, 683-84 (S.D.N.Y. 1953).

It is copy-book law that "uniformity" in the "means" used by the parties to a conspiracy is never the question. See Direct Sales Co. v. United States, 319 U.S. 703 (1943). The essence of conspiracy lies in the "scheme" or plan, not in the means or elements which "give to the scheme a body" and perhaps suffice "to accomplish it." Holmes, J., in Swift \& Co. v. United States, 196 U.S. 375, 396 (1905). Defendants must be shown to have given "their adherence to the scheme and participated in it," but in no other sense has "uniformity" ever been a requirement. Stone, J., in Interstate Circuit, Inc. v. United States, 306 U.S. 208, 226 (1939) (emphasis added). 
the court disposed of each of these, one at a time, in piecemeal fashion, contrary to the most elementary rules in conspiracy cases. ${ }^{32}$ The result, surely, was manifest error of law.

\section{The "Revolution"}

Finally, according to Mr. Whitney, "Government counsel wholly failed to appreciate, until confronted by statistical data at the trial, that a revolution has occurred in investment banking ...."33 W' hatever may have been the "competitive condition" of the industry "in the period 1934-1937,"34 and Mrr. Whitney concedes there may once have been "some sort of a code or ethic not to compete,"35 it existed no longer, for "the business was revolutionized thereafter."36 "Yet, strangely enough," Mr. Whitney goes on to say, "the bulk of the exhibits upon which the Government particularly relied came from the period of 1934-1937."37

The plea, it will be noted, is one in confession and avoidance. But Mr. Whitney seems to have overlooked the fact that the complaint was filed on October 30, 1947. It is not strange at all, therefore, that most of the significant documentary evidence in the case came from an earlier period. ${ }^{3 s}$ Moreover, contrary to Mr. Whitney's statement that the court was to be "primarily concerned"39 with the period 1947-1949 in determining whether to enter a decree, the exact opposite is true. In a rational world, the question whether a conspiracy existed on October 30,1947 , as charged, must necessarily be established in the main by evidence from periods prior to that time. ${ }^{20}$

32. See Steffen, p. 187-8S. Paragraph 44A(5), relating to defendants' use of resale price agreements, penalties, and so on, was treated still differently. To the court it was neither "means," "term" or "charge," but a superfluous allegation to be disposed of in a "dictum." United States v. Morgan, 118 F. Supp. 621, 686 (S.D.N.X. 1953).

33. Whitney, p. 339.

34. Id. at 342 .

35. Id. at 339 .

36. Id. at 342 .

37. Ibid.

38. It would have been more than strange, in a realistic world, if much significant evidence were to have found its way into the defendants' files while the pre-complaint investigation was actually under way, or, for that matter, from the time when the Government filed its brief in the P.S.I. case. National Association of Securities Dealers, Inc., 19 S.E.C. 424 (1945). Moreover, as Charles E. Mitchell of Blyth \& Co. testificd, with commendable frankness, it may have become less customary to write things out for the files:

Q. Three of the members of your Executive Committee are on the West Cosst and the balance are here on the East Coast? A. That is right.

Q. What means of communication do you use? A. Well, we used letter writing to a greater degree for some years and used our own private-wire system. In later years a'e haze gotten wiser and use the telephone call."

Transcript of Record, p. 5823, United States v. MLorgan, 118 F. Supp. 621 (S.D.N.Y. 1953) (emphasis added).

39. Whitiney, p. 342.

40. See United States v. E.I. du Pont de Nemours \& Co., 11 F.R.D. 303 (D. Del. 1951) ; Note, 65 HARv. L. Rev. 1079 (1952). 
It is a separate question whether a conspiracy-once established-is likely to continue. Post-complaint evidence goes primarily to that issue. ${ }^{41}$ But, for reasons not hard to see, it is a customary defense tactic, as in this case, for counsel to seek to confuse the two. Perhaps the court can be persuaded, on the basis of post-complaint evidence of good behavior, to hold that no conspiracy ever existed in the first place. Of course, post-complaint good behavior is sometimes not very hard to bring about. If the antitrust laws could have been avoided by such means, they would long since have become a dend letter. The Supreme Court, however, made it very clear quite early that a court is not to be ousted of jurisdiction by evidence of a last minute conversion. ${ }^{42}$

Mr. Whitney's supposed "revolution," moreover, leaves much to be desired. It amounts to no more than some data, known to everyone, and in part introduced by the Government, which show that "compulsory public sealed bidding' 43 has narrowed the field in which the defendant bankers can still operate on a continuing-banker, private-negotiation basis, that is to say, by the method of doing business challenged by the complaint.44 But the area is still very large, for it includes the whole field of industrial securities. And, although "private placements" have made sizeable inroads upon this part

41. See United States v. Standard Oil Co., 78 F. Supp. 850 (S.D. Cal. 1948), aff'd, 337 U.S. 293 (1949). Certain of the contracts there sought to be enjoined, far from having been cancelled, were shown actually to have been renewed after the complaint was filed. No better evidence of the continning nature of the alleged violation could well have been given.

42. See, e.g., United States v. Trans-Missouri Freight Ass'n, 166 U.S. 290, 307 (1897), where Mr. Justice Peckham said, in part, "we think the fact of the dissolution of the association does not prevent this court from taking cognizance of the appeal and deciding the case upon its merits." Cf. United States v. W.T. Grant Co.', 345 U.S. 629, 632 (1953).

43. The SEC adopted Rule U-50, in 1941, to require competitive bidding for the securities of registered public utility holding companies, and, in 1944 the ICC ordered competitive bidding for railroad debt issues. Contrary to $\mathrm{Mr}$. Whitney, this was quite well known to Government counsel. In fact, the defendants' campaign in opposition to competitive bidding was alleged, in paragraph $44 \mathrm{C}$ of the complaint, as a "term" of the conspiracy in restraint of trade, charged in paragraph 43 . The data introduced by the Government showed-without contradiction-that, while the defendants managed $73.24 \%$ of all issues of $\$ 1,000,000$ or over sold on a private negotiation basis, during the period 19351949 , they were able to manage only $55.66 \%$ of all issues of $\$ 1,000,000$ or over sold at competitive bidding during the period. Exhibit 111 (f), Transcript of Record, p. 7806, United States v. Morgan, 118 F. Supp. 621 (S.D.N.Y. 1953). Exhibit 111(c) showed that while defendants had managed $92.78 \%$ of railroad issues sold on a negotiated basis, nondefendant bankers were able to get $53.86 \%$ of the business done at competitive biddling during the period. If this was a "revolution," it was one only in the sense that for the first time defendants were required to sharpen their pencils and quote competitive prices, something they did with only indifferent success.

44. See Steffen, p. 173. No objection was ever raised by the Government to use of syndicates, as such. In fact, the more syndicates, the better, if that would mean real pricccompetition, and a break-up of the "reciprocity," "historical position," and "interlocking director" practices, common in the industry. 
of defendants' domain, that surely is no "revolution." In fact, Mr. Whitney makes it fairly clear in conclusion that no revolution at all has taken place in any significant sense, but that the defendant bankers will continue their operations, much as in the past. ${ }^{45}$ And why not? Judge Medina's action in dismissing the case, "with prejudice," is a virtual license so to do.40

The conclusion is irresistible that it was not a "revolution" in the industry, which caused the Government's case to "evaporate." The mischief was done in the course of the openings, when, if I too may use MIr. IVhitney's words, the court was subjected to nearly four months of a sort of "brain washing": by defense counsel. A fairly simple case charging a conspiracy to eliminate price-competition in the purchase and sale of securities was turned into a thing of mystery and contradiction by much talk. Mr. Whitney alone talked, with great skill and charm, for some sixteen court room days in succession, ${ }^{48}$ to say nothing of his many interjections and comments at all other times. The "revolution"-if any-was one in trial practice.

The case must necessarily have been reversed, if the Antitrust Division had taken an appeal. As it is, however badly discredited, the decision will no doubt be venerated for many years to come as the investment bankers' bible. Surely, though, no trial court will soon again adopt Judge Medina's guiding principle that, no matter how "minute and lacking in substance" their points might be-and far too many were vulnerable on both counts $^{40}$-he would

45. Whitney, p. 343-44.

46. A counter-revolution, moreover, is well under way. On February 18 and March 31, 1954, several of defendant bankers or their counsel appeared in Washington, with Judge Mredina's opinion in hand, to urge that the SEC should now modify its Rule U-50, in order to exempt a large category of public utility securities from the present requirement of competitive bidding. Transcript of Proceedings, Oral Argument on Rule U-50, pp. 1, 170 (1954). The following defendant bankers were represented directly: Blyth \& Co., Morgan Stanley \& Co., Smith, Barney \& Co., Lehman Brothers. The opposition came from nondefendant bankers, joined by Robert $R$. Young and a few others.

47. Whitney, p. 321. Mr. Whitney implies that, without the "extended openings," the court would have been "bewildered and, from the defense point of view, subjected to a sort of pro-plaintiff brain washing." That is surely an unfortunate way to describe the orderly presentation of evidence even in a wholly documentary case, where, of course, the court is presented with whatever is necessary to get accurately the plaintiff's version of the case. (There is a proper time for the defendants to put in their case.) The openings here, however, went round and round, with counsel for the seventeen defendants giving their several versions of how the industry really operates, of what the complaint really charged, and of what the Government's proposed exhibits really meant, all weels and months before any evidence at all had been presented. Mforeover, contrary to Mr. Whitney's statement that appeal on this ground was waived by a remark of Government counsel in the course of argument, Whitney, p. 320, the fact is that formal exception was talsen on the record. See Transcript of Record, p. 5584, United States v. MIorgan, 118 F. Supp. 621 (S.D.N.Y. 1953).

48. Jan. 23, 1951 to Feb. 20, 1951, Transcript of Record, pp. 2182-3401, United States v. Morgan, 118 F. Supp. 621 (S.D.N.Y. 1953).

49. No point of purported banking practice was so small-or so irrelevant-but that hours might be spent in listening to the unsupported assertions of defense counsel giving 
"listen to the lawyers till the cows came home."50 Trial by colloquy must not be allowed to supplant time honored notions of fair trial.

their versions of the matter, and much else. It is little wonder, therefore, that Judge Medina lost track of the Government's basic charges. In fact, as the case wore along, he necessarily began even to lose the line between evidence and mere assertion of counsel. One example: Without any evidence whatever in the record he allowed himself to find "that truckloads of documents were produced before the Grand Jury," something doubly improper since Grand Jury proceedings are secret. United States v. Morgan, 118 F. Supp. 621, 731 (S.D.N.Y. 1953).

50. Medina, Judge Medina Speaks 54 (1954). Although Judge Medina goes on to say that such a thing is impossible, "at least if you want to preserve your health," id. at 55, the extremely long record in the Bankers' case, unfortunately, bears witness on nearly every page that he felt bound to make the sacrifice. 